\title{
Zinc Finger Protein 479
}

National Cancer Institute

\section{Source}

National Cancer Institute. Zinc Finger Protein 479. NCI Thesaurus. Code C143105.

Zinc finger protein 479 (524 aa, $\sim 61 \mathrm{kDa}$ ) is encoded by the human ZNF479 gene. This protein may be involved in transcriptional repression. 